\title{
Evaluation of Two Exotic Apple Varieties on M9T337 for Growth and Quality Attributes under Kashmir Conditions
}

\author{
Rafiya Mushtaq*, A.H. Pandit, Mohammad Tauseef Ali, Kousar Javaid, \\ M.K. Sharma, Amarjeet Singh and Danish Bashir
}

Division of Fruit Science, Sher-Kashmir University of Agricultural Science and Technology, Kashmir, India

*Corresponding author

\section{A B S T R A C T}

\begin{tabular}{|l|}
\hline K e y w o r d s \\
Apple varieties, \\
M9T337, High \\
density, Quality, \\
Yield
\end{tabular}

\section{Introduction}

The apple is the most ubiquitous of temperate fruits and has been cultivated in Europe and Asia from antiquity.The genetic variability found in the apple has allowed adapted types to be selected for different environments, and selection continues for new types to extend apple culture in both colder and warmer regions. Almost entire fruit plantation in the state is on seedling origin rootstock. The vigorous seedling rootstock leads to larger trees, which have long juvenility. There is more competition between vegetative growth and fruit production within these trees and their internal self-shading makes them more vulnerable to various diseases (Robinson, 2003). By using vigorous rootstocks, only few trees can be accommodated per hectare making the productivity less profitable. With stagnation in productivity, looming threat of imported fruits and land prices touching new peaks in the valley, it becomes imperative to go for high-density plantation for which change in rootstock from vigorous to size controlling rootstock is a prerequisite. For the temperate zone to prosper in apple, it is imperative to shift to new varieties which have 
both high yield potential as well as good marketability. In order to solve the problems of low productivity, poor quality, less colour and irregular bearing habits in current apple plantations in Kashmir valley, two apple varieties namely Super Chief Sandidge and Fuji Zehn Aztec were evaluated for various morphological and fruit characteristics at SKUAST-K Shalimar with the objective to study the performance of newly introduced apple varieties for growth and quality attributes under high density conditions.

\section{Materials and Methods}

Two exotic varieties of apple grafted on M-9 T337 rootstock were introduced by SKUASTKashmir in spring 2013 from an Italian nursery, GRIBA, Italy. The plant material was one year old with 3 plus feathers. The trees of uniform size, vigour and bearing capacity were selected for experimentation located at Shalimar campus of SKUAST-Kashmir and were evaluated for various growth and quality characteristics. All the trees received uniform cultural practices during the year under study as per the package of practices of SKUASTKashmir. The experiment was laid in Randomized Complete Block Design (RCBD) with five replications and two trees per treatment as plot size.

\section{Growth characteristics}

\section{Tree height (m)}

The height of selected trees was measured from the bud union to the top of tree in meters and average value was recorded.

\section{Tree trunk cross sectional area $\left(\mathrm{cm}^{2}\right)$}

Tree trunk cross sectional area of each experimental unit was measured $15 \mathrm{~cm}$ above bud union and expressed as $\mathrm{cm}^{2}$ using following formula:

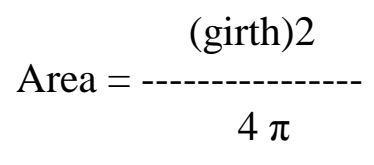

\section{Shoot length (cm)}

The shoots that were more than $15 \mathrm{~cm}$ in length were taken and shoot length was recorded with the help of measuring tape and expressed in centimeter.

\section{Leaf area $\left(\mathrm{cm}^{2}\right)$}

The leaf area of each sample comprising of 30 leaves was collected at random from different directions of each experimental tree and measured with the help of a leaf area meter (221 systronics) and expressed in square centimeters.

\section{Initial bloom (DARD)}

The stage was observed visually when 10 per cent of flowers were open.

\section{Full bloom (DARD)}

The stage was observed when 80 per cent of flowers were open.

The date of occurrence was recorded for each tagged tree.

\section{Fruit set (\%)}

It was calculated by using the following formula and expressed in percentage:

No. of fruitlets at pea stage
Fruit set $(\%)=\frac{\text { No. of flowers }}{----} \times 100$

\section{Fruit leaf ratio}

The number of leaves per fruit of each experimental unit were counted and averaged. 


\section{Yield per tree $(\mathrm{kg})$}

The crop harvested from each experimental unit was recorded and expressed in kilogram per tree.

\section{Quality characteristics}

\section{Fruit weight (g)}

Ten fruits from each treatment in each replication were weighed individually on a sensitive monopan balance and average weight was recorded in grams.

\section{L/D ratio}

L/D ratio was calculated by dividing the length of fruit with the diameter of corresponding fruit and shape of fruit was determined as per the following procedure.

$\mathrm{L} / \mathrm{D}$ ratio $1=$ Round; $\mathrm{L} / \mathrm{D}$ ratio $>1=$ Oblong; $\mathrm{L} / \mathrm{D}$ ratio $<1=$ Flat

\section{Total Soluble Solids $\left({ }^{0} \mathrm{Brix}\right)$}

A hand refractrometer ranging from 0-33 $\left({ }^{\circ}\right.$ Brix Erma make Japan) was used to determine TSS and values were corrected at $20{ }^{\circ} \mathrm{C}$.

\section{Titrable acidity (\%)}

Acidity was determined by taking a known weight of fruit sample (10 g) which was crushed and added to $100 \mathrm{ml}$ distilled water, then filtered through Whatman's No. 1 filter paper. $10 \mathrm{ml}$ of aliquot was titrated against $\mathrm{N} / 10 \mathrm{NaOH}$ using phenolphthalin indicator and end point was determined by pink colouration. The total titrable acidity was calculated in terms of malic acid on the basis of $1 \mathrm{ml}$ of $0.1 \mathrm{~N} \mathrm{NaOH}$ solution equivalent to 0.0067 and expressed in terms of per cent acidity (A.O.A.C., 1990). Acidity was calculated as malic acid by using the following formula:

Titre value $\times$ normality of alkali $\times$ Dilution $\times 67$

$$
\begin{gathered}
\text { Acidity }(\%)=\text { Weight of sample } \times \\
\text { Volume of aliquot taken } \times 1000
\end{gathered}
$$

\section{Number of seeds/fruit}

Fruits were cut and seeds removed from the core and number was counted. Chaffy and shriveled seeds were discarded.

\section{TSS/Acid ratio}

Total soluble solids/acid ratio was determined using the formula:

TSS/Acidity ratio $=\frac{\text { Total Soluble Solids (\%) }}{\text { Acidity }(\%)}$

\section{Juice yield (\%)}

A known weight of fruit at random from each treatment in each replication was sampled for juice content. The seeds were extracted from fruits and the pulp was macerated with the help of juicer grinder. The juice was collected in a jar and its quantity was measured in measuring cylinder. The percent juice content was calculated using the equation:

Juice per cent $=\frac{\text { Volume of juice }(\mathrm{L})}{\text { Weight } \text { of fruit }(\mathrm{kg})}$

\section{Results and Discussion}

The variety Super Chief Sandidge showed a minimum tree height $(1.31 \mathrm{~m})$ compared to Fuji Zehn Aztec (1.96m). Trunk cross sectional area was recorded more in Fuji Zehn Aztec $\left(4.70 \mathrm{~cm}^{2}\right)$ than Super Chief Sandidge 
$\left(3.72 \mathrm{~cm}^{2}\right)$. The overall reduced vigour of all the trees may be attributed to the dwarfing rootstock as the hypothesis is that dwarfing rootstock, or possibly its graft union alters the ratios and concentrations of the growth promoting hormones and also the inhibiting hormones which are translocated within the tree (Ferree and Warrington, 2003, Micheal, 2009). Our results are supported by the findings of Kiprijanovski et al., (2002) who reported that the cultivar Fuji Kiku 8 had the largest trunk cross sectional area and canopy area at the end of the sixth year. Leaf area was recorded maximum in Super Chief Sandidge $\left(43.21 \mathrm{~cm}^{2}\right)$ and minimum in Fuji Zehn Aztec $\left(32.65 \mathrm{~cm}^{2}\right)$. The variation among the varieties may be varietal or due to other environmental factors. The leaf area is considered one of the most important components of the fruiting structures involved in the fruit size and quality because branches with a large leaf area present a higher photosynthetic capacity, reducing the competition for photosynthates with other branches (Costes, 2003). The first flower opening and end of flowering was observed earlier in Super Chief Sandidge (45.35DARD and 57.28 DARD respectively) than Fuji Zehn Aztec (47.85DARD and 60.36DARD). The differences in the phenological stages may be due to their genetic differences or the differential chilling requirements of these varieties may be the reason for such variations. Fruit set percent was recorded highest in Super Chief Sandidge (62.55\%) and lowest in Fuji Zehn Aztec (57.48\%).

Our research results were in conformity with the findings of Madial et al., (2010) who reported that low fruit set in Fuji is due to high amount of vegetative buds in this cultivar. It has been suggested that there should be 30-40 leaves for the quality production of a single fruit. However, for high density plantation this number is relatively low which was confirmed in our research. The highest fruit leaf ratio was observed in variety Fuji Zehn Aztec (31.29) while the least ratio was observed in variety in Super Chief Sandidge (25.28), as it is highly spur variety. The maximum average yield was recorded in Super Chief Sandidge $(2.45 \mathrm{~kg} /$ tree $)$ compared to Fuji Zehn Aztec $(2.05 \mathrm{~kg} /$ tree $)$ (Table 1$)$.

Table.1 Growth characteristics of two exotic varieties

\begin{tabular}{|l|c|c|c|c|c|c|c|c|c|}
\hline Variety & $\begin{array}{c}\text { Tree } \\
\text { Height }(\mathbf{m})\end{array}$ & $\begin{array}{c}\text { TCSA } \\
\left(\mathrm{cm}^{2}\right)\end{array}$ & $\begin{array}{c}\text { Shoot } \\
\text { length }(\mathrm{cm})\end{array}$ & $\begin{array}{c}\text { Leaf area } \\
\left(\mathrm{cm}^{2}\right)\end{array}$ & $\begin{array}{c}\text { First Flower } \\
\text { Opening } \\
(\text { DARD) }\end{array}$ & $\begin{array}{c}\text { End of } \\
\text { flowering } \\
\text { (DARD) }\end{array}$ & $\begin{array}{c}\text { Fruit set } \\
(\%)\end{array}$ & $\begin{array}{c}\text { Fruit leaf } \\
\text { ratio }\end{array}$ & $\begin{array}{c}\text { Yield } \\
(\mathrm{kg} / \text { tree })\end{array}$ \\
\hline $\begin{array}{l}\text { Super Chief } \\
\text { Sandidge }\end{array}$ & 1.31 & 3.72 & 89.45 & 43.21 & 45.35 & 57.48 & 62.55 & 25.11 \\
\hline $\begin{array}{l}\text { Fuji Zehn } \\
\text { Aztec }\end{array}$ & 1.96 & 4.70 & 100.20 & 32.65 & 47.85 & 62.55 & 57.48 & 31.29 \\
\hline Cd $(\mathbf{p} \leq \mathbf{0 . 0 5})$ & $\mathbf{0 . 4 0}$ & $\mathbf{0 . 2 8}$ & $\mathbf{1 . 1 9}$ & $\mathbf{0 . 8 9}$ & $\mathbf{0 . 3 0}$ & $\mathbf{1 . 0 8}$ & $\mathbf{1 . 9 9}$ & $\mathbf{0 . 3 5}$ & $\mathbf{0 . 1 3}$ \\
\hline
\end{tabular}

Table.2 Quality characteristics of two exotic varieties

\begin{tabular}{|l|l|l|l|l|l|l|l|}
\hline Variety & $\begin{array}{l}\text { Fruit } \\
\text { weight }(\mathrm{g})\end{array}$ & L/D ratio & $\begin{array}{l}\text { Number of } \\
\text { seeds/fruit }\end{array}$ & $\begin{array}{l}\text { TSS } \\
\left({ }^{\circ} \text { Brix }\right)\end{array}$ & $\begin{array}{l}\text { Total acidity } \\
(\%)\end{array}$ & $\begin{array}{l}\text { TSS/acid } \\
\text { ratio }\end{array}$ & $\begin{array}{l}\text { Juice yield } \\
(\%)\end{array}$ \\
\hline $\begin{array}{l}\text { Super Chief } \\
\text { Sandidge }\end{array}$ & 193.99 & 0.87 & 9.60 & 14.12 & 0.20 & 70.34 & 70.51 \\
\hline $\begin{array}{l}\text { Fuji Zehn } \\
\text { Aztec }\end{array}$ & 157.62 & 0.77 & 7.56 & 12.40 & 0.32 & 39.67 & 67.41 \\
\hline Cd $(\mathbf{p} \leq \mathbf{0 . 0 5})$ & $\mathbf{3 3 . 4 2}$ & $\mathbf{0 . 0 5}$ & $\mathbf{1 . 0 5}$ & $\mathbf{0 . 9 6}$ & $\mathbf{0 . 0 5}$ & $\mathbf{5 . 7 1}$ & $\mathbf{0 . 5 7}$ \\
\hline
\end{tabular}


Fruit weight was recorded maximum in Super Chief Sandidge (193.99g) than Fuji Zehn Aztec $(157.62 \mathrm{~g})$. The variation in fruit weight may be due to varietal characters and presence of seeds in the fertilized fruits as the fruits containing seeds with endosperm are the sites of giberrellic acid synthesis, where growth substances are produced. Fuji Zehn Aztec appeared to be more flat in shape (0.77) and Super Chief Sandidge round (0.87).Number of seeds per fruit were recorded maximum in Super Chief Sandidge (9.60).According to Currie et al., (2000), a very common pattern to express this fruit shape is the length/diameter ratio. Our research results were further supported by the findings of Madial et al., (2010), who reported that Fuji produces more flattened fruits with an average of 0.79 . Super Chief Sandidge showed high TSS (14.12 ${ }^{\circ}$ Brix) and low acidity $(0.20 \%)$ while variety Fuji Zehn Aztec showed TSS of $12.40{ }^{\circ}$ Brix and acidity $(0.32 \%)$. The TSS/acid ratio is a key characteristics of determine the taste, texture and feel of fruit segments. It is sugar/acid ratio which contributes towards giving many fruits their characteristic flavour. This ratio was found highest in variety Super Chief Sandidge (70.34). The variation among varieties may be due varietal difference, environmental factors, difference in the sugar content of varieties (Table 2). These characters are also influenced by climatic and moisture availability during the growing season. According to Hudina et al., (2001), the applied agrotechnical and pomotechnical measures such as fertilization, irrigation and the training systems can influence these parameters. The study revealed that both the varieties performed well under Kashmir conditions, however the variety Super Chief Sandidge showed better performance interms of both yield and quality attributes compared to Fuji Zehn Aztec. It can be suggested that in variety Super Chief Sandidge further close plantings at the rate of 3906 trees/ha can be recommended to utilize the inter-tree space more efficiently and the productivity further high.

\section{References}

A.O.A.C. 1980. Methods of Analysis; $14^{\text {th }}$ ed. Association of Official Agriculture Chemists. Washington, D.C; USA 957.

Costes, E. 2003. Winter bud content according to position in 3-year old branching system in Granny Smith apple. Annuals of Botany 92: 581-588.

Currie, A.J., Ganeshanandan, S., Noiton, D.A., Garrick, D., Shelbourne, C.J.A. and Oraguzie, N. 2000. Quantitative evaluation of apple (Malus $\times$ domestica Borkh.) fruit shape by principal component analysis of Fourier descriptors. Euphytica 111: 219227.

Ferrec, D.C. and Warrington, I.J. 2003. Apples: Botany, Production and Uses. CABI Publication.

Hudina, M., Stampar, F. and Zadravec, P. 2001. The Influence of Planting Density on Sugar and Organic Acid Content in Apple. Acta Horticulturae 557: 313-320.

Kiprijanovski, M., Arsov, T., Gjanovski, V. and Damovski, K. 2002. Study of certain introduced apple cultivars in the Prespa region. Acta Horticulturae 825: 125-132.

Madail, R.H., Herter, F.G., Leite, G.B. and Petri, J.L. 2010. Influence of flower structure in the flower production and fruit set in some apple cultivars. Acta Horticulturae 872: 309-311.

Robinson, T.L. 2003. Apple orchard planting system. In: Apples (Eds. D.C., Ferrec and I.J., Warrington), Cabi Publ., Wallingford, UK. Pp: 345-407.

\section{How to cite this article:}

Rafiya Mushtaq, A.H. Pandit, Mohammad Tauseef Ali, Kousar Javaid, M.K. Sharma, Amarjeet Singh and Danish Bashir. 2018. Evaluation of Two Exotic Apple Varieties on M9T337 for Growth and Quality Attributes under Kashmir Conditions. Int.J.Curr.Microbiol.App.Sci. 7(03): 2828-2832. doi: https://doi.org/10.20546/ijcmas.2018.703.325 